\title{
System of biological protection of corn against pests for organic farming
}

\author{
Vladimir Ismailov* \\ Federal Research Centre of Biological Plant Protection, Krasnodar, 350039, Russian Federation
}

\begin{abstract}
This study discusses promising methods of biological control of the main corn pests, based on the integrated use of pheromones, entomopathogenic preparations and the release of parasitic hymenoptera Trichogramma evanescens West. and Habrobracon hebetor Say. Seasonal dynamics of flying and the number of cotton moth Helicoverpa armigera Hbn. and Kuban click beetle Agriotes tauricus Heyd. were determined by capturing males with pheromone traps. Species composition of corn pests, the dynamics of flying and the number of dominant pests of the cotton moth $H$. armigera and corn moth Os. nubilalis are determined, the optimal dates for protective measures (release of entomophages - Trichogramma and Habrobracon, treatment with biological products) are set. As a result of the field assessment of the biological control system of the main corn pests, we determined the satisfactory efficacy of the mutually suppressing techniques based on using Trichogramma and Habrobracon entomophages and biological preparations based on entomopathogenic bacteria and viruses. The corn bioprotection efficacy against the stem corn moth was 84 $\%$ in the early hybrid and $94 \%$ in the late one, against the cotton moth $82,2-77,8 \%$, respectively.
\end{abstract}

\section{Introduction}

Annually, losses caused by corn pests make up 10-20\% of the yield on average, and with mass propagation, grain damage can exceed $30 \%$. At the same time, not only the yield decreases, but also the quality of the grain deteriorates.

Corn is one of the most vulnerable crops to pests, of which the stem corn moth Ostrinia nubilalis Hbn, the cotton moth Helicoverpa armigera Hbn., the black corn aphid Rhopalosiphum maidis Fitch, wireworms (Coleoptera, Elateridae), and Oulema melanopus L. cause the major damage. Although corn has a rather plastic attitude to the group of dangerous factors - pests, there are several representatives, the action of which brings significant damage to productivity with a possible decrease in the quality characteristics of products. [1-4].

Corn (stem) moth Os. nubilalis is a pest of thick-stemmed crops. The main nature of the harmfulness is damage to the core of the stems, vascular-fibrous bundles, the prevention of nutrient intake, which is accompanied by severe dehydration of the plant, increased fragility of the stems and, as a result, a decrease in productivity. Most of the time, the caterpillars of

\footnotetext{
* Corresponding author: vlyaism@yandex.ru
} 
the moth feed secretly, making passages inside plants, most often stems, where they penetrate in the first or third (corn) age [5-7]. Their activity often leads to damage to the base of the ear, as a result of which the latter takes the vertical position prematurely. Caterpillars that have completed feeding overwinter inside plant debris. To a significant extent, the development of the pest is facilitated by poor-quality treatment of plant residues, in which the bulk of the corn moth is concentrated for the next season $[8,9]$.

The cotton moth $H$. armigera is a polyphagous pest that damages at least 250 species of cultivated and weed plants in different parts of the range. Some of the highly preferred plants are the tomato Lycopersicon lycopersicum L. and the corn Zea mays L. In Krasnodar Krai the cotton moth develops in three generations. The overwintered generation of the phytophage colonizes first weeds, alfalfa, the subsequent generations - tomato, soybeans and corn. H. armigera can also cause great harm to tobacco plants [10]. The ectoparasite Habrobracon hebetor Say (Hymenoptera, Braconidae), known as a parasite of more than 60 species of lepidopteran pests, is a promising bioagent capable of reducing the chemical load on corn crops. Gabrobragon females are able to penetrate into various holes, cracks, and other places where phytophagous caterpillars settle, in particular the stem corn moth and other moths, which feed inside the stalks, fruits, and ears [11, 12].

The aim of the research is to develop an ecologized corn protection system for organic farming technologies.

\section{Materials and methods}

The studies were carried out on a stationary crop rotation of the Federal Research Center of Biological Plant Protection (FRCBPP) on corn crops on hybrid Krasnodarsky 291 AMV with an area of 1 hectare (2018-2020) and Agronova LLC, Labinsky District of Krasnodar Krai on hybrids GS-370, KSS-5230 3 ha (2019).

The seasonal dynamics of flying and the abundance of the cotton moth $H$. armigera and Kuban click beetle Agriotes tauricus Heyd were determined by capturing males with pheromone traps. For this purpose, on experimental corn plots with an area of $50 \mathrm{~m}^{2}$ in advance, 10-15 days before the beginning of the seasonal flying, 3 traps of Atracon A with the pheromone of the cotton moth and Estren traps with the pheromone of the Kuban click beetle were installed. The counts were carried out twice a week during the entire growing season.

Counting the number of caterpillars of the cotton moth $H$. armigera was carried out before the formation of ears on 20 corn plants at different points of the field on 20 ears in 5 replicates.

Counting the number of caterpillars of the corn moth Os. nubilalis was carried out on 15 plants at different plots in 6-7 replicates. At the end of the growing season, the corn stems were cut at soil level, split lengthwise to the base with a knife, and the stem moth caterpillars were counted in the stems before harvesting.

Mass breeding of the gabrobracon ectoparasite $H$. hebetor for biological control of the corn moth and cotton moth was carried out using the large bee moth (Galleria mellonela L.) as a host insect. Caterpillars of older age of the large bee moth, 100-400 ind. were placed on corrugated paper in glass jars with a capacity of 1-3 liters for the purpose of contamination with gabrobracon. In each jar, 50-70 individuals of the entomophage are placed, which paralyze the caterpillars and lay eggs on them. After 10-14 days. after the emergence of adult parasites, they are packaged in glass jars with a capacity of $0.25-0.5$ liters and released on corn crops during the appearance of the corn moth and cotton moth middle age caterpillars at the rate of 1-2 thousand individuals per 1 ha [6].

To control Oulema melanopus L. we carried out the treatment with a bio-rational preparation Vertimec ${ }^{\circledR}$ CE (Syngenta AG, Switzerland) at a consumption rate of $1.2 \mathrm{l}$ / ha. 


\section{Results and discussion}

In 2018-2019, the main phytophages were identified on corn crops, which include the corn (stem) moth Os. nubilalis, cotton moth H. armigera, winter moth (Agrotis segetum Schiff), exclamation moth (Agrotis exclamationis L), gamma moth (Authographa gamma L), small (terrestrial) caradrin (Laphygma exigua $\mathrm{Hb}$ ). On the experimental plots, the following species of click beetles was identified: the Kuban click beetle - A tauricus.

The corn crops were close to the barley crops, as a result of which, at the end of the growing season of barley, the migration of Oulema melanopus $\mathrm{L}$ to the experimental plots of corn were observed. The number of Oulema melanopus L was 3-5 individuals / plant. The counting carried out after the treatment showed that the number of the pest significantly decreased and amounted up to 0.5 individuals / plant.

In the middle of May, glue traps with cotton moth pheromone were hung on experimental plots. In 2018, there were three distinct generations of the cotton moth with flying peaks in late June, July and mid-August. A characteristic feature of the phenological development of the cotton moth in 2019 was a very high abundance of the overwintered pest generation, which was confirmed by the mass capture of males from 15 to 35 individuals / trap in the first ten days of June (Fig. 1). Since the second decade of June, the number of males in pheromone traps significantly decreased to single individuals by the end of June. The beginning of butterflies flying of the first cotton moth summer generation was noted on July 3, after which the nuptial fly-out of the pest was continuous with the maximum capture of males on July 3, 28 and August 21, which amounted up to 10-15 ind./trap.

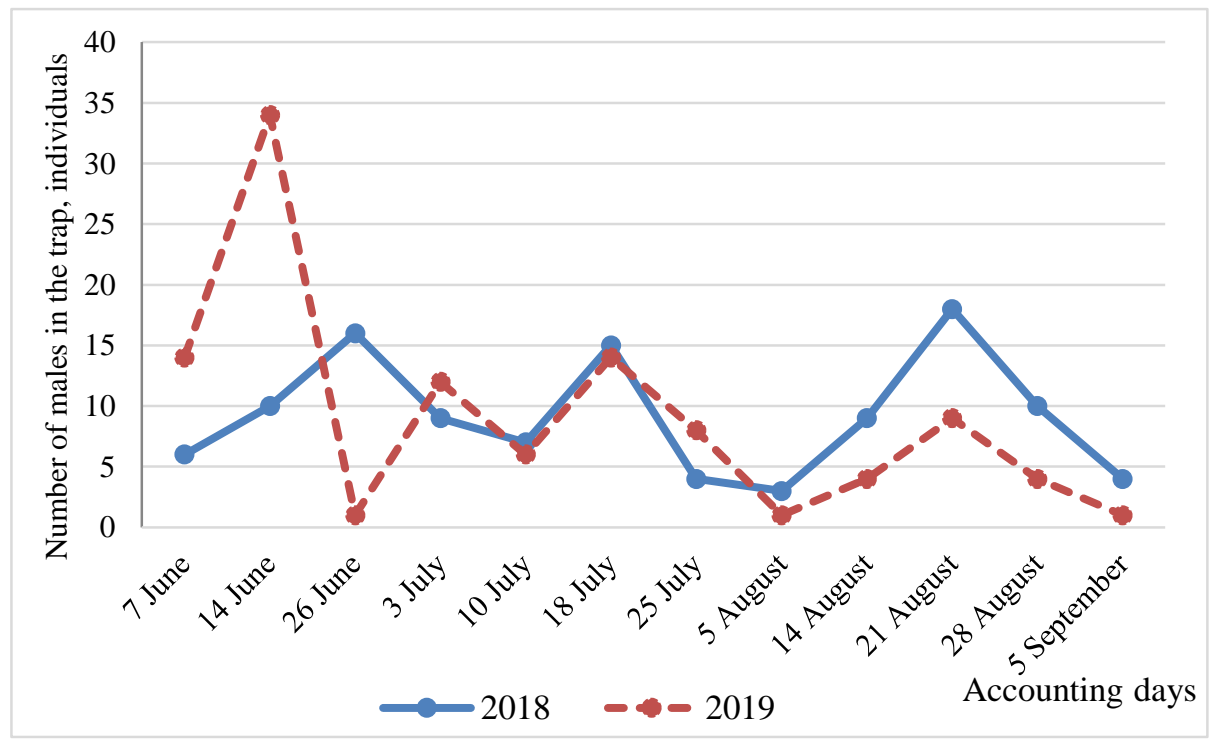

Fig. 1. Dynamics of flying of male cotton moth H. armigera Hb. 2018-2019

To determine the number of wireworms (larvae of click beetles), click beetles were monitored. In the middle of June, traps with a synthetic pheromone of Kuban click beetle $A$. tauricus were set (Figure 2). 


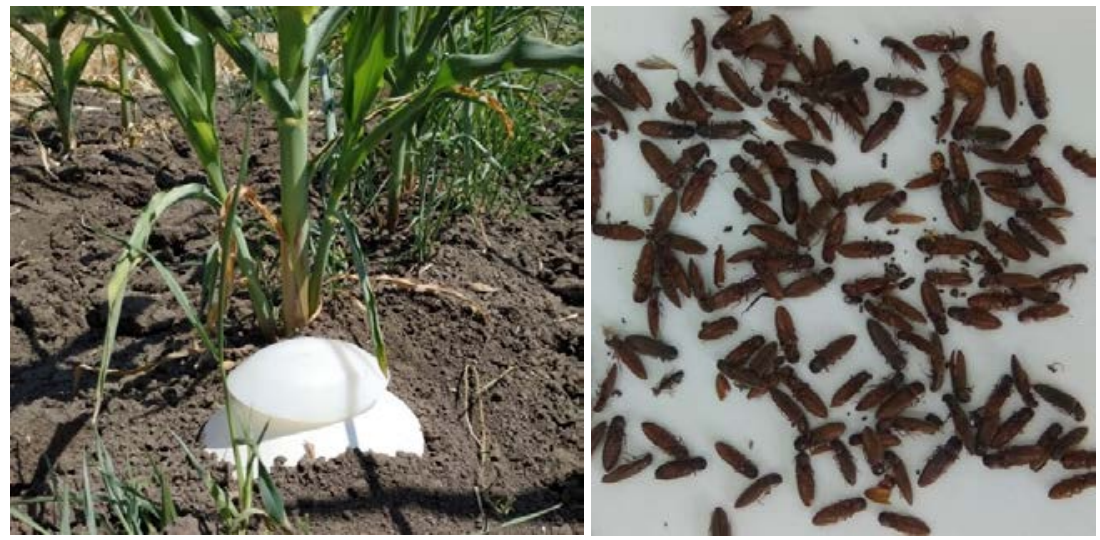

Fig. 2. Pheromone trap for catching male Kuban click beetle A. tauricus Heyd

It was found that flying of the Crimean click beetle males in pheromone traps began in the third part of June and amounted up to 19.6 individuals per trap on average per week, and the maximum capture peak of 160 individuals / trap was recorded on July 17. Based on the number of beetles caught during the seasonal flying of the Kuban click beetle (June 21, 2018 - August 7, 2018), using the mathematical model that we developed, the number of larvae (wireworms) was determined, which was $1.7 \mathrm{ind} . / \mathrm{m}^{2}$.

The main indicator of harmfulness of the stem corn moth Os. nubilalis is damage to the pith of the stems. The trichogramma Trichogramma evanescens West was released twice on the eggs of the corn moth and cotton moth, at the rate of $3 \mathrm{~g}$ of infected eggs of sitotroga (150-200 thousand Trichogramma specimens) per 1 ha. Then, after the emergence of caterpillars of the stem corn moth and cotton moth, treatments were carried out with the preparations Lepidocid, P-3 kg / ha + Helicovex $0.2 \mathrm{l} / \mathrm{ha}$, and with the appearance of middle-aged caterpillars of these pests, 2 releases of gabrobragon ectoparasite were produced at the rate of 1500-2000 individuals / ha (table 1).

Decisions on protective measures were taken strictly based on the results of monitoring, taking into account the number of pests determined by capturing males with pheromone traps, visual observations, mowing with an entomological net, as well as identifying the levels of efficiency of entomophages (LEE) of the ratio of pests and their entomophages.

The results presented in the table 1 show that the efficacy of biological protection of corn against stem corn moth was $74.1 \%$ in the early hybrid and $94.0 \%$ in the late, cotton moth $-72.2 \%$ and $77.8 \%$, respectively.

Table 1. Biological efficacy of corn complex protection against the main pests

\begin{tabular}{|c|c|c|c|c|c|c|c|c|c|}
\hline \multirow[t]{2}{*}{ Hybrids } & \multirow[t]{2}{*}{$\begin{array}{l}\text { Insect } \\
\text { species }\end{array}$} & \multicolumn{7}{|c|}{$\begin{array}{c}\text { Number of insects, ind. for } 1 \text { plant., } \\
\text { by dates of counts }\end{array}$} & \multirow{2}{*}{$\begin{array}{l}\text { Biological } \\
\text { efficacy, } \\
\%\end{array}$} \\
\hline & & 3.07 & 10.07 & 19.07 & 24.07 & 2.08 & 13.08 & total & \\
\hline \multirow{2}{*}{$\begin{array}{l}\text { Hybrid } \\
\text { Krasnodarsky } 291 \\
\text { AMV (early } \\
\text { ripening) }\end{array}$} & Corn moth & 0 & 0 & 0,3 & 0 & 0 & 0 & 0,3 & 74,1 \\
\hline & Cotton moth & 0 & 0,12 & 0,08 & 0 & 0,3 & 0,7 & 1,2 & 72,2 \\
\hline \multirow{2}{*}{$\begin{array}{l}\text { Hybrid } \\
\text { Krasnodarsky } 455 \\
\text { MB(late ripening) }\end{array}$} & Corn moth & 0 & 0 & 0,07 & 0 & 0 & 0 & 0,07 & 94,0 \\
\hline & Cotton moth & 0 & 0,06 & 0,1 & 0 & 0,3 & 0,5 & 0,96 & 77,8 \\
\hline \multirow{2}{*}{$\begin{array}{l}\text { Control (without } \\
\text { treatment) }\end{array}$} & Corn moth & 0,38 & 0,18 & 0,6 & 0 & 0 & 0 & 1,16 & - \\
\hline & Cotton moth & 0 & 0,51 & 0,7 & 0,9 & 1,0 & 1,2 & 4,31 & - \\
\hline
\end{tabular}


Thus, as a result of a field assessment of the biological control system of the main pests of corn, a satisfactory efficacy of complementary techniques based on the use of entomophages of Trichogramma and gabrobracon and biological products based on entomopathogenic bacteria and viruses was determined. The species composition of corn pests was clarified, the dynamics of flying and the number of dominant corn pests was determined: the cotton moth $H$. armigera and the corn moth Os. nubilalis, the optimal timing of protective measures was established (release of entomophages - trichogramma and gabrobracon, treatment with biological products).

When protecting corn against the main pests, great importance should be given to the compatibility of entomophages with biological and bio-rational pesticides. To preserve the introduced and natural populations of entomophages, and to restore the mechanisms of natural biocenotic regulation, it is possible to preferentially use a number of environmentally low-hazard products identified as a result of the research.

The research was carried out in accordance with the State Assignment No. 075-00376-19-00 of the Ministry of Science and Higher Education of the Russian Federation within the framework of research work on the topic No. 0686-2019-0009.

\section{References}

1. Frolov A.N., Malysh Yu.M. Density of placement and mortality of eggs of young caterpillars of the corn moth on corn plants, Bulletin of plant protection, 2004, 1, P.1525.

2. Darnhofer I., Lindenthal T., Bartel-Kratochvil R., Zollitsch W. Conventionalisation of organic farming practices: from structural criteria towards an assessment based on organic principles. A review, Agronomy for Sustainable Development, 2011, 30 (1), P. 67-81 (doi: 10.1051/agro/2009011).

3. Biology and Management of Pest Diabrotica Species in South America / G. Cabrera Walsh, C.J. Ávila, N. Cabrera et al. // Insects. 2020. Vol. 11. No 7. P. - 421. doi: https://doi.org/10.3390/insects11070421.

4. Fefelova Yu.A., Frolov A.N. Factors of seasonal dynamics of the cotton moth number in Krasnodar Krai, Bulletin of plant protection, 2007, 1, P. 20-37.

5. Bengtsson J., Ahnstrom J., Weibull A.C. The effects of organic agriculture on biodiversity and abundance: a meta-analysis, Journal of Applied Ecology, 2005, 42 (2), P. 261-269 (doi: 10.1111/j.1365-2664.2005.01005.x).

6. Agasyeva I.S., Ismailov V.Ya. The role of biotechnology in biological plant protection, Proceedings of the Kuban State Agrarian University, 2016, 58, P. 67-74.

7. Agasyeva I.S., Umarova A.O., Development of the methods of biological protection of corn against the main pests, Agrotechnical method of plant protection against harmful organisms: mater. int. scientific and practical conf., Krasnodar: KubSAU, 2017, P. 1619

8. Ismailov V.Ya., Agasyeva I.S., Kil V.I., Fedorenko E.V., Besedina E.N., Nefedova M.V. Study of the biological characteristics of the ectoparasite Habrobracon hebetor Say in order to optimize the biocenotic regulation of the number of harmful Lepidoptera, Kuban Science, 2017, 4, P. 26-33.

9. Tolerance in Maize Landraces to Diabrotica speciosa (Coleoptera: Chrysomelidae) Larvae and Its Relationship to Plant Pigments, Compatible Osmolytes, and Vigor / E. N. Costa, B. H. Sardinha de Souza, Z. A. Ribeiro, J Econ Entomol. 2021. Vol. 114. No 1. P. - 377-386. doi: https://doi.org/10.1093/jee/toaa292. 
10. Kher S.V., Dosdall, L. M., Cárcamo, H. A. Biology, host preferences and fitness of Oulema melanopus (Coleoptera: Chrysomelidae), a recent invasive pest in Western Canada, Arthropod-Plant Interactions. 2016. No 10 P., 365-376. https://doi.org/10.1007/s11829-016-9446-8.

11. Genome sequence of the corn leaf aphid (Rhopalosiphum maidis Fitch) / Chen W., Shakir S., Bigham M. et al., Gigascience. 2019. Vol. 8. No 4. P. 1-12. doi: https://doi.org/10.1093/gigascience/giz033.

12. The Spread of Helicoverpa armigera (Lepidoptera: Noctuidae) and Coexistence with Helicoverpa zea in Southeastern Brazil, F. A. Pinto, M. V. V. Mattos, F. W. S. Silva et al., Insects. 2017. Vol. 8. No 3. P. - 87. doi: https://doi.org/10.3390/insects8030087 